\title{
Analyzing Students Pauses During Reading and Explaining a Story
}

\author{
Sibel Denisleam (Molomer) \\ Computer Science Department \\ University Politehnica of Bucharest \\ Bucharest, Romania \\ d_sybelle@yahoo.com
}

\author{
Stefan Trausan-Matu \\ Computer Science Department \\ University Politehnica of Bucharest \\ and \\ Research Institute for Artificial Intelligence \\ Bucharest, Romania \\ and \\ Academy of Romanian Scientists \\ stefan.trausan@cs.pub.ro
}

\author{
Philippe Dessus \& \\ Maryse Bianco \\ LSE \\ Univ. Grenoble Alpes \\ Grenoble, France \\ philippe.dessus@upmf- \\ grenoble.fr
}

\begin{abstract}
In this paper we present a semi-automated analysis of student reading performance from the perspective of her text reading level and text understanding. Silences (pauses) between uttered words or read sentences as well as silences between verbalizations given by students are the key points in the analysis of their learning activities. Pause is an essential element in the analysis of a text, which also gives good control over interactions during the processes of text reading and explanation of understanding. This study presents the results specific to pauses in the reading and verbalization using Praat, a tool to analyze spoken productions. Correlations between students' fluency, story understanding, and mean pause duration of reading and explanation phases show consistent results across texts for reading. Results about pauses during explaining yielded low correlations, showing that other variables may influence the pausing behaviors during explaining.
\end{abstract}

Keywords-Pause, Reading, Explanation

\section{INTRODUCTION}

Communication is the central point in analyzing any type of face-to-face or instant messenger (chat) conversation and it is based on words, groups of words, phrases or images. Communication can be also considered from the perspective of the written or transcribed text as it is used in reading, explaining, chat as well as other types of conversations. In both perspectives, the analysis of the pauses during production of either spoken or written words may reveal the employed strategies [1].

The current paper is based on an experiment with French native speakers aged between 9 and 11 years old in which they are asked to read a text and then explain its content [2] at predetermined break points. This presupposes a student-teacher communication based on an analysis of what the student understood from the content of the text. The pauses in speaking, reading out loud are one of the factors to account for in the analysis process. They reveal important properties about the students' performance in the understanding process, in explaining the content of the written text and in reading the text itself.

The next sections of this study are considering the main components of pauses, aiming to analyze the student's level of understanding in the reading stage as well as explaining, and ends with an experiment which highlights calculation processes of the reading/explanation pause length. The above aspects will help us emphasize the term "pause" according to the understanding of the text read.

\section{SPECIFIC COMPONENTS OF PAUSE ANALYSIS PROCESS}

Three components are necessary for the manual analysis process: pause, pause length, and pauses structure. We start from the term "silence" first described in 1996 by Petit [3] and continue with the presentation of the term seen from Sacks' perspective in the form of gaps, interruptions, and pauses [4]. The description continues with the presentation of the concept of "hesitation", described by Grosjean \& Deschamps [5] and includes filled pauses, elongated syllables, repetition, false starts.

Pause, the first component of the analysis process, is the moment of silence during reading a text or explaining it. A pause before uttering words (phenomenon encountered in our experiment) shows that the student is experiencing some difficulty in the reading or comprehending process, while a pause before an explanation may show that the student lacks knowledge and cannot make connections with other ideas to express the content or did not fully understand the text content. So, the pause may arise during reading the text or explaining it, with different causes.

Pause length is the temporal interval from the moment of interruption of reading/explanation until resuming verbalization or text reading.

Pauses structure is given by the number and types of pauses. In addition, during text reading or explaining, pauses may exist or may be absent, which means that we can highlight two cases, present and absent pauses [6]. For example, in our experiment, we can identify an absence of an explanation pause in the following transcribed paragraph: 
"Donc le serpent il lui dit que il a pas du tout peur de lui et que ses flèches elles feront rien et du coup le Dieu ben il lui lance une flèche dans le cou et puis voilà."

and we can highlight the presence of a pause like this:

“ben y va ... y va donc bah ... avec son ch'val et puis bah y dit au dragon de ... da les nuages recracher tous les nuages aura une punition ... qu'y mérit."

Depending on the pause length, they may appear in the form of long pauses or short pauses [7]. We find these pause types among several authors such as Kendall [8] or Campioni [9] and we will also use them in the experiment. Pauses between words or sentences may indicate some difficulties in reading or oral expressing, but they also may have the role to convey an intention of what the student wants to express. The difference between short and long pauses is distinguished by the fact that a short pause has the role to share ideas in a sentence and thus text comprehension is better and student's explanation is more correct. For the exemplification we will show the following paragraph containing short pauses, giving the student the possibility to totally express the content of the reading text.

“Alors en fait ben ... y a quelqu'un et ben y dit euh que ça peut plus continuer pace que la Terre elle est en train de mourir de soif. Donc euh et ben y dit qu'y va ... aller arrêter donc Indra c'ui qui boit toute l'eau. Et vu qu'il est ... féroce fort et ... voilà. Et ben ... y a ses amis y disent que euh ben que va s'faire manger.

Long pauses differ from the short ones by the positive or negative aspect they present. The positive aspect relates to a longer reading time but a correct verbalization as the silence moment allows a higher memory retrieval and attention and the negative aspect may present a difficult verbalization, precisely because time is very long and the ability to concentrate may be lost.

It was noted in analyzing the results of the experiment that the number of short pauses is preferred instead of the long ones, being also proved in other several experiments that short pauses indicate that students have a better control than long pauses. The negative aspect present in the following two explanations, shows us that a very long pause gives the student the impossibility to continue his idea:

"elle euh...elle...dit elle dit euh ben elle dit...(LONG SILENCE) euh...Matilda s'est dépensée fin (Elle ?) elle dit elle dit elle dit des choses...et euh (NON UNDERSTANDABLE) (Et ?j'ai pas entendu - je sais plus donc on continue)."

"Euh...dans la pièce euh tous...euh (LONG SILENCE) dans la pièce... ah oui bah y entendent à nouveau le bruit et le ensuite y regardent autour d'eux...y rig non non non non j'peux r'commencer? (oui si tu veux-d'accord) "

\section{EXPERIMENT}

During the experiment, 9-11 years old French speaking students (19 Grade 3 students and 18 Grade 5 students, respectively "Cours Élémentaire 2" / "Cours Moyen 2") read in turn two stories (Matilda and The Cloud Swallower) made of 56 paragraphs, each story containing about 350-450 words. Their task was to read a part of the story and then to stop at pre-determined break points and to orally explain (to verbalize) what they had understood from the story up to this point. We will analyze, based on the notion of pause, the level of understanding a read or spoken text.

\begin{tabular}{|c|c|}
\hline & $\begin{array}{l}\text { Le soleil brillait de toutes ses forces et les dieux qui vivaient sur } \\
\text { la Terre trouvaient qu'il faisait trop chaud. Les dieux racontèrent } \\
\text { à Indra qu'ils avaient vu le grand serpent Ati étirer sa tête jusque } \\
\text { dans le ciel pour avaler les nuages qui passaient. Ati avait si soif } \\
\text { qu'il buvait toute l'eau des nuages : voilà pourquoi il ne tombait } \\
\text { plus une goutte de pluie. }\end{array}$ \\
\hline \multirow[t]{2}{*}{ E1 } & $\begin{array}{l}\text { C'est un serpent qui s'appelle Ati // } \\
\text { et qui... qui a soif et... qui donc, i va, i tire sa tête e vers les } \\
\text { nuages, et... et il boit toute l'eau des nuages. }\end{array}$ \\
\hline & $\begin{array}{l}\text { Indra ne trouva pas cela drôle du tout. À cause de ce glouton, la } \\
\text { Terre entière mourait de soif! - " Ça ne peut pas continuer, } \\
\text { décida le jeune dieu. Je vais délivrer les nuages et libérer la } \\
\text { pluie ». Ses amis s'affolèrent. Ati était grand et féroce. Indra } \\
\text { allait sûrement se faire manger lui aussi. }\end{array}$ \\
\hline \multirow[t]{2}{*}{ E2 } & $\begin{array}{l}\text { ET ben le jeune dieu, et ben, il va libérer la ville? Et parce que } \\
\text { les... les gens du village et ben i mourraient de soif. }\end{array}$ \\
\hline & $\begin{array}{l}\text { Sans les écouter, Indra prit un arc et des flèches bizarres, jaunes } \\
\text { et toutes tordues : des éclairs. Puis il sauta à cheval. En route } \\
\text { pour le ciel! Il prit son élan, galopa, ouvrit ses ailes et décolla. } \\
\text { C'était un cheval volant! Un peu plus tard, Ati attrapa un petit } \\
\text { nuage. Il s'apprêtait à le gober quand il entendit un battement } \\
\text { d'ailes et une voix qui lui criait: - « Si tu ne relâches pas } \\
\text { immédiatement tous les nuages que tu as avalés, tu auras la } \\
\text { punition que tu mérites! }\end{array}$ \\
\hline \multirow[t]{2}{*}{ E3 } & $\begin{array}{l}\text { Et ben c'est le... serpent, Ati, ben i... il...ne, Il ne veut pas qu'on } \\
\text { libère la pluie pour donner à boire aux gens et il. .. Ils... et le } \\
\text { jeune dieu et ben il le fait quand même. }\end{array}$ \\
\hline & $\begin{array}{l}\text { Le serpent tout gonflé d'eau se tortilla de rire. - « Hi hi hi ! Ce } \\
\text { jeune fou croit que j'ai peur de lui, de son drôle d'arc et de ses } \\
\text { flèches tordues! » Indra tendit son arc et visa le cou du serpent. - } \\
\text { «Tu vas voir de quoi mes flèches sont capables. }\end{array}$ \\
\hline \multirow[t]{2}{*}{$\mathrm{E} 4$} & $\begin{array}{l}\text { Le serpent il est dégonflé, il est gonflé d'eau et il dit qu'il n'a pas } \\
\text { peur des flèches et de l'arc de Indra. Et... et il. Et hum... i fait } \\
\text { avoir par une flèche. }\end{array}$ \\
\hline & $\begin{array}{l}\text { "Ouille! " fit Ati dans un hoquet quand la première flèche le } \\
\text { toucha. Et un petit nuage s'échappa de sa gueule ouverte. - } \\
\text { "Ouille! Ouille! Ouille! " Indra lança trois autres éclairs et à } \\
\text { chaque cri du serpent un nuage se sauvait, laissant enfin tomber } \\
\text { la pluie sur la Terre. Effrayé, Ati se sauva à toute vitesse. Indra } \\
\text { rejoignit ses amis qui lui firent un accueil triomphal : grâce à lui, } \\
\text { la saison sèche est terminée. }\end{array}$ \\
\hline E5 & $\begin{array}{l}\text { C'est Indra euh i tire sur e le serpent et à chaque fois que le } \\
\text { serpent fait ouille ya un nuage qui sort. }\end{array}$ \\
\hline $\begin{array}{l}\text { Sum } \\
\text { mary }\end{array}$ & $\begin{array}{l}\text { C'est un serpent qui a soif et qui, qui euh, étira sa tête vers les } \\
\text { nuages et qui boit toute l'eau des nuages et après et ben les gens } \\
\text { du village ils peuvent plus boire parce qu'i a plus d'eau don Indra } \\
\text { i i tire des flèches sur le serpent et, et, le serpent, ben à chaque } \\
\text { fois qu'il fait ouille des nuages qui sortent, qui sortent de ... } \\
\text { hum... }\end{array}$ \\
\hline
\end{tabular}

Fig. 1. Reading and explanation of a student on The Cloud Swallower story 
The example in Fig. 1 is made up of the five paragraphs of the text given to students, each paragraph being followed by the student's explanations (coded En) and ended by a summary of the entire story (coded summary).

The means through which the content of the read text and its rendering was checked was represented by identifying the pauses made while reading and the pauses in which the student explains the content of the text read. Thus, it is easy for teachers to assess a student's level, to compare the level of text understanding with the level of student's expression..

Using the Praat software package [10] we calculated the total duration of the reading process (words and pauses), the duration of the silences while reading the text, the duration of the silences during expressing the content, the number of words in the read text and the number of words while explaining the content.

We will now briefly present the steps used to extract the moments of silence and of sound, respectively, by means of Praat [10].

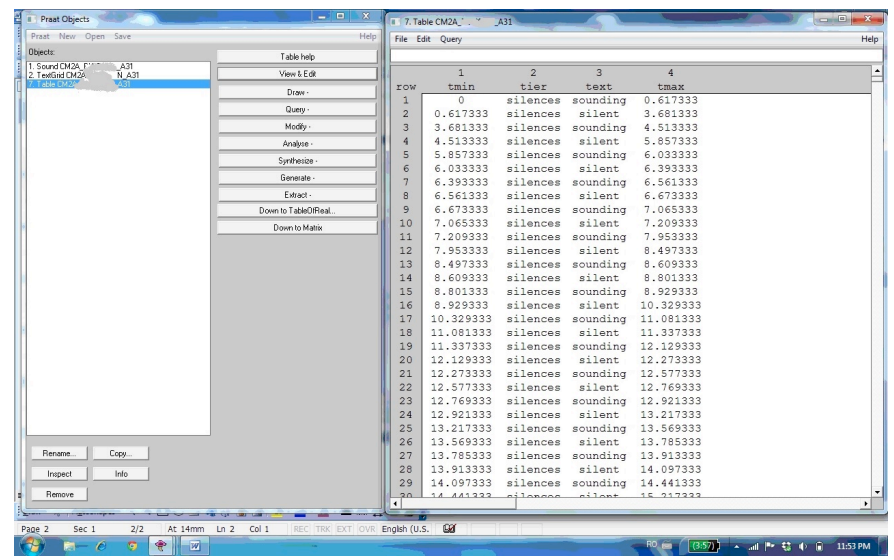

Fig. 2. The interface of Praat [10]

The data extraction operation allows us to view the starting moment of the reading/verbalization, and the closing moment, viewing the total length of reading and verbalization, as well as the moments of silence and sound.

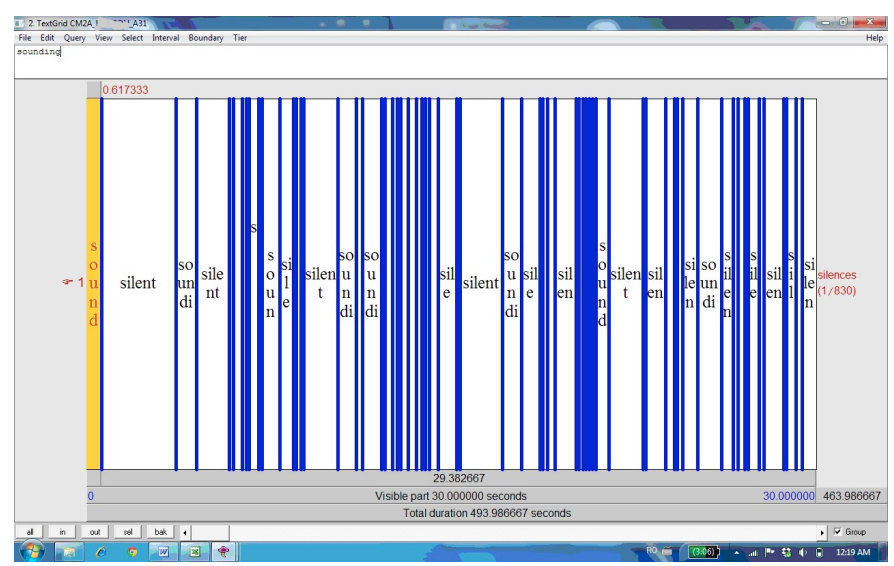

Fig. 3. Example of extracting silence/sound using Praat [10]
The next step was represented by the calculation of the duration of the text reading and speaking according to the total number of words read/spoken and the total number of pauses made while reading/speaking.

In Table I is shown an example of the dataset extracted for student \#1; it shows the total reading duration as the sum of the duration of reading words and the total length of pauses, and the total verbalization duration as the sum of the duration of speaking and the total length of pauses.

TABLE I. DURATIONS OF WORDS AND PAUSES OF AN AUDIO FILE (STUDENT \#1).

\begin{tabular}{|c|c|c|c|c|}
\hline $\begin{array}{l}\text { File } \\
\text { ID }\end{array}$ & $\begin{array}{l}\text { Total reading } \\
\text { duration } \\
\text { of words }\end{array}$ & $\begin{array}{l}\text { Total } \\
\text { pauses } \\
\text { while } \\
\text { reading }\end{array}$ & $\begin{array}{l}\text { Total } \\
\text { duration of } \\
\text { reading }\end{array}$ & $\begin{array}{l}\text { Number of } \\
\text { read words }\end{array}$ \\
\hline 1 & $108.38 \mathrm{~s}$ & $166.24 \mathrm{~s}$ & $274.62 s$ & 355 \\
\hline $\begin{array}{l}\text { File } \\
\text { ID }\end{array}$ & $\begin{array}{l}\text { Total words' } \\
\text { explanation } \\
\text { duration }\end{array}$ & $\begin{array}{l}\text { Total } \\
\text { pauses } \\
\text { while } \\
\text { explaining }\end{array}$ & $\begin{array}{l}\text { Total } \\
\text { duration of } \\
\text { explanation }\end{array}$ & $\begin{array}{l}\text { Number of } \\
\text { spoken } \\
\text { words }\end{array}$ \\
\hline 1 & $31.72 \mathrm{~s}$ & $82.27 \mathrm{~s}$ & $113.99 \mathrm{~s}$ & 215 \\
\hline
\end{tabular}

The analysis of the texts is done considering the words uttered by the students while reading the story and while rendering the content of the text. Based on these aspects, the analysis of Grade 3 and 5 students was performed, thereby yielding the values presented in Table II for the specific minimum and maximum of the total duration of pauses during reading and during explaining.

The presented text is described first of all by means of the number of words uttered by the students during the explanations, the number of words in the story, the duration of reading/speaking and the two types of speed reading/speaking.

TABLE II. MINIMUM AND MAXIMUM TOTAL DURATIONS OF PAUSES WHILE READING AND WHILE SPEAKING

\begin{tabular}{|l|l|r|c|}
\hline Grade/Story & \multicolumn{1}{|c|}{ Pauses } & $\begin{array}{c}\text { Minimum } \\
\text { Duration }\end{array}$ & $\begin{array}{c}\text { Maximum } \\
\text { Duration }\end{array}$ \\
\hline Grade 3/ & while reading & $71.24 \mathrm{~s}$ & $440.38 \mathrm{~s}$ \\
\cline { 2 - 4 } Matilda & while explaining & $69.79 \mathrm{~s}$ & $214.65 \mathrm{~s}$ \\
\hline $\begin{array}{l}\text { Grade } \\
\text { 3/Swallower }\end{array}$ & while reading & $79.58 \mathrm{~s}$ & $240.07 \mathrm{~s}$ \\
\cline { 2 - 4 } & while explaining & $58.46 \mathrm{~s}$ & $145.73 \mathrm{~s}$ \\
\hline Grade & while reading & $61.49 \mathrm{~s}$ & $203.63 \mathrm{~s}$ \\
\cline { 2 - 4 } 5/Swallower & while explaining & $46.02 \mathrm{~s}$ & $122.72 \mathrm{~s}$ \\
\hline $\begin{array}{l}\text { Grade } \\
\text { 5/Swallower }\end{array}$ & while reading & $49.91 \mathrm{~s}$ & $166.24 \mathrm{~s}$ \\
\cline { 2 - 4 } & while explaining & $38.94 \mathrm{~s}$ & $132.04 \mathrm{~s}$ \\
\hline
\end{tabular}

We computed $r$ correlations between two measures (student fluency and story understanding) and mean pause duration of reading and explanation phases (see Table III). Results show consistent results across texts for reading: fluency, as expected, is inversely correlated with pauses (the more fluent the reader the less he or she pauses); likewise, the higher the comprehension score on the read text, the lower the pauses are. Results about pauses during explaining yielded low correlations, showing that other variables may influence the pausing behaviors during explaining. Deeper analyses, 
separated by kind of strategies used by students were not conclusive as well.

TABLE III. CORRELATIONS BETWEEN FLUENCY SCORE, STORY UNDERSTANDING SCORE, AND PAUSE DURATION, BY READ TEXT $(* *<.01 ; *<.05)$

\begin{tabular}{|c|c|c|c|c|}
\hline $\begin{array}{c}\text { Pauses/ } \\
\text { Stories }\end{array}$ & \multicolumn{2}{|c|}{ Grade 3 $(N=19)$} & \multicolumn{2}{c|}{ Grade 5 $(N=18)$} \\
\hline Matilda & Fluency & Underst. & Fluency & Underst. \\
\hline $\begin{array}{c}\text { While } \\
\text { Reading }\end{array}$ & $-.75^{* *}$ & -.36 & $-.71^{* *}$ & $-.59^{*}$ \\
\hline $\begin{array}{c}\text { While } \\
\text { Explaining }\end{array}$ & -.20 & .20 & -.15 & -.36 \\
\hline $\begin{array}{c}\text { Cloud } \\
\text { Swallower }\end{array}$ & $-.62^{* *}$ & $-.56^{* *}$ & $-.65^{* *}$ & -.40 \\
\hline $\begin{array}{c}\text { While } \\
\text { Reading }\end{array}$ & -.15 & -.02 & -.31 & -.08 \\
\hline $\begin{array}{c}\text { While } \\
\text { Explaining }\end{array}$ & & & & \\
\hline
\end{tabular}

\section{CONCLUSION}

Pauses have a very important role in reading and explaining a text. We devised a scalable semi-automated workflow to get and analyze pause-related data from an experiment with French speaking 9-11 years old students.

Starting from the directions presented in the paper about understanding a read text, rendering the content of the text read, and analyzing the pauses that appear while reading or explaining, the following research directions are worth considering.

First, we aim at performing a deeper analysis between the self-explanation strategies [11] automatically or manually generated in relation with the speed of speaking/reading, and with the pauses made while reading/speaking. Second, we aim at generating an automated assessment of students comprehension, thus creating a marking scheme according to the explanations offered, the time taken to answer, the pauses included in the speaking process and their duration Third, we aim at replicating this kind of analyses with chat conversations in correlating the pauses with some audio files in which students directly present the ideas of a text. An analogy can be made between the reading of a narrative and orally rendering the content of the text but also between a text read in a chat environment and rendering the content of the text in a written form.

\section{ACKNOWLEDGEMENTS}

This work has been partly funded by the French ANR DEVCOMP project (ANR-10-BLAN-1907-01) and the Sectoral Operational Programme Human Resources Development 2007-2013 of the Ministry of European Funds through the Financial Agreement POSDRU/159/1.5/S/13239.

\section{REFERENCES}

[1] Chanquoy, L., Foulin, J.-N., \& Fayol, M., Temporal management of short text writing by children and adults. European Bulletin of Cognitive Psychology, vol. 10, pp. 513-540, 1990.

[2] Dascalu, M., Dessus, P., Bianco, M. \& Trausan-Matu, S., Are automatically identified reading strategies reliable predictors of comprehension? In S. Trausan-Matu, E. Boyer, M. Crosby, \& K.
Panourgia (Eds.), $12^{\text {th }}$ Int. Conf. on Intelligent Tutoring Systems (ITS 2014). New York, Springer, LNCS 8474, pp. 456-465, 2014.

[3] Candea, M., Contribution à l'étude des pauses silencieuses et des phénomenes dits "d'hésitation" en francais oral spontané. PhD Thesis, Université Paris III-Sorbonne, 2000.

[4] Sacks, H, Schegloff, E. A. \& Jefferson, G. A., A simplest systematics for the organization of turn-taking in conversation. Language, vol. 50, pp. 696-735, 1974

[5] Grosjean, F., \& Deschamps, A, Analyse contrastive des variables temporelles de l'anglais et du français. Phonetica, vol. 31, pp. 144-184, 1975.

[6] Swerts, M. \& Krahmer, E, Audiovisual prosody and feeling of knowing. J. Memory Language, vol. 53, pp. 81-94, 2005.

[7] Brennan, S.E. \& Williams, M., The feeling of another's knowing: Prosody and filled pauses as cues to listeners about the metacognitive states of speakers. J. Memory Language, vol. 34, pp. 383-398, 1995.

[8] Kendall, T., Speech rate, pause, and linguistic variation: An examination through the sociolinguistic archive and analysis project, $\mathrm{PhD}$ Thesis, Graduate School of Duke University, 2009.

[9] Campione, E. \& Véronis, J., A large scale multilingual study of silent pause duration. In B. Bel \& I. Marlien (eds.), Proc. Speech Prosody Conf., Aix-en-Provence, Laboratoire Parole et Langage, pp. 199-202, 2002.

[10] Boersma, P., \& Weenink, D. (2015). Praat: doing phonetics by computer [Computer program]. Version 5.4.01, Retrieved 20 August 2015 from http://www.praat.org/

[11] McNamara, D. S., SERT: Self-Explanation Reading Training. Discourse Processes, vol. 3, pp. 1-30, 2004. 